\title{
TINDAKAN KEBIRI BAGI PELAKU KEKERASAN SEKSUAL TERHADAP ANAK (KAJIAN PERSPEKTIF HUKUM ISLAM DAN HUKUM POSITIF DI INDONESIA)
}

\author{
Desy Maryani \\ Fakultas Hukum Universitas Dehasen Bengkulu (UNIVED) \\ Jl. Meranti Raya No.32, Sawah Lebar, Ratu Agung, Bengkulu, 38222 \\ Email: desymaryani1985@gmail.com
}

\begin{abstract}
The government needs to re-examine the provision of additional punishment that is considered a violation of human rights violated human rights and not in accordance with Islamic Shari'a. The results of the study show that (1) the punishment of the noble violates the Shari'a of Islam so it is forbidden with three reasons: a) Islamic shari'ah has unlawfully prohibited the human being, without any dissenting opinion (khilafiyah) among fuqaha, b) Islamic shariah has set penalties for pedophile who commit acts of immorality and rape according to the details of the facts of his deeds, so that it may not (haram) carry out any kind of punishment outside the provisions of Islamic Sharia, c) in the case of the method of using a chemical injection method, namely injected estrogen hormone, from the other side, because it resulted in castrated men having physical characteristics such as women. Yet Islam has forbidden men to resemble women or vice versa women resemble men. (2) In the regulation of legal policy for perpetrators of sexual violence against children is contained in the Criminal Code and the issuance of Law no. Law No. 23 of 2002, Law no. 35 of 2014 until the issuance of Law no. 1 Year 2016 on Child Protection.
\end{abstract}

Keywords: Action of Left, Sexual Actor, Islamic Law and Positive Law

Abstrak: Pemerintah perlu mengkaji ulang tentang pemberian hukuman tambahan yaitu tindakan kebiri yang dinilai melanggar Hak Asasi Manusia (HAM) dan tidak sesuai dengan syariat islam. Hasil penelitian menunjukkan (1) hukuman kebiri melanggar syariat islam sehingga diharamkan dengan tiga alasan yaitu a) syariah Islam dengan tegas telah mengharamkan kebiri pada manusia, tanpa ada perbedaan pendapat (khilafiyah) di kalangan fuqaha, b) syariah Islam telah menetapkan hukuman untuk pelaku pedofilia yang melakukan tindakan pencabulan dan pemerkosaan sesuai rincian fakta perbuatannya, sehingga tidak boleh (haram) melaksanakan jenis hukuman di luar ketentuan Syariah Islam itu, c) dalam hal metode kebiri yang digunakan adalah metode injeksi kimia, yakni yang diinjeksikan adalah hormon estrogen, hukumnya juga haram dari sisi lain, karena mengakibatkan laki-laki yang dikebiri memiliki ciri-ciri fisik seperti perempuan. Padahal Islam telah mengharamkan laki-laki menyerupai perempuan atau sebaliknya perempuan menyerupai laki-laki. (2) Dalam regulasi kebijakan hukum bagi pelaku kekerasan seksual terhadap anak terdapat dalam KUHP dan dikeluarkannya UU No. 23 Tahun 2002, UU No. 35 Tahun 2014 sampai dengan dikeluarkan UU No. 1 Tahun 2016 tentang Perlindungan Anak.

Kata kunci: Tindakan Kebiri, Pelaku Seksual, Hukum Islam dan Hukum Positif 


\section{Pendahuluan}

Anak adalah generasi penerus yang akan datang. Baik buruknya masa depan bangsa tergantung pula pada baik buruknya kondisi anak saat ini. Berkaitan dengan dengan hal tersebut, maka perlakuan terhadap anak dengan cara yang baik adalah kewajiban kita bersama, agar ia bisa tumbuh berkembang denganbaik menjadi pengemban risalah peradaban bangsa ini. Pasal 16 ayat (3) Deklarasi umum tentang Hak Asasi Manusia (DUHAM) menentukan bahwa keluarga adalah kesatuan alamiah dan mendasar dari masyarakat dan berhak atas perlindungan oleh masyakarakat dan negara, DUHAM adalah instrument international HAM yang memiliki sifat universal, dalam arti setiap hak-hak yang diatur didalamnya berlaku untuk semua manusia didunia tanpa kecuali. Di dalam UU No.39 Tahun 1999 tentang Hak Asasi Manusi, dirumuskan 15 pasal yang khusus merumuskan hak-hak anak, karena pembentuk UU menyadari bahwa anak merupakan kelompok yang rentan terhadap pelanggaran HAM. Hal ini sudah sesuai dengan peratifikasian Konvensi Hak-Hak Anak berdasarkan keputusan Presiden nomor 36 TAhun 1990 tentang Pengesahan Convention On The Right Of The Child (Konvensi tentang Hak-Hak Anak/KHA), maka sejak tahun 1990 tersebut Indonesia terikat secara hukum untuk melaksanakan ketentuan yang termaktub di dalam Konvensi Hak-Hak Anak ${ }^{1}$.

Konvensitersebut mengemukakan tentang prinsip-prinsip umum perlindungan anak yaitu non diskrimiansi, kepentingan terbaik anak, kelangsungan hidup dan tumbuh kembang dan menghargai partisipasi anak ${ }^{2}$. Akan tetapi hingga keluarnya Undang-Undang Perlindungan Anak dan sampai sekarang, kesejahteraan dan pemenuhan hak anak masih jauh dari yang diharapkan. Hal tersebut dapat dilihat dari berulangnya kekerasan seksual terhadap anak.

Maraknya tindak pidana kekerasan seksual terhadap anak saat ini, dilihat dari banyaknya kasus-kasus kekerasan seksual yang terjadi pada tahun 2014-2016, di antaranya:

${ }^{1}$ Nasir Djamil,Anak Bukan Untuk Dihukum catatan Pembahasan UU Sistem Peradilan Pidana Anak (UU-SPPA),(Jakarta Timur: Sinar Grafika, 2015),hal. 18

2 Rika Saraswati, Hukum Perlindungan Anak Di Indonesia, (Bandung: Citra Aditya Bakti, 2015), hal. 1 a. Kasus AS (24 tahun) alias Emon yang disebut sebagai predator seksual yang haus bocah untuk disodomi. Kekerasan seksual yang dilakukan oleh AS mencapai 73 orang 3 .

b. Kasus pria berinisial MS berusia 35 tahun memperkosa AS seorang bocah berumur 13 tahun yang merupakan keponakannya pelaku4

c. Kasus pencabulan yang dilakukan Syanwani alias Iwan/IW (45 tahun). Tertangkapnya pria yang berprofesi tukang ojek ini, diketahui adanya laporan kalau pelaku sudah melakukan pencabulan terhadap delapan orang anak, yakni BS (12), MMD (15), RR (15), RN (14), MIS (15), NSH (11), NK (13), FRH (13)

d. Kasus pemerkosaan dan pembunuhan terhadap seorang anak perempuan yang berinisial PNF yang berumur 9 tahun, PNF ditemukan dalam keadaan tanpa busana dan terbungkus kardus di Kalideres, Jakarta Barat. Dari hasil autopsi korban, diketahui PNF meninggal dengan cara kekerasan seksual. Persetubuhan itu dilakukan dengan cara kekerasan dan berakibat meninggal dunia ${ }^{6}$.

e. Kasus pemerkosaan dan pembunuhan terhadap Yuyun (14), warga Desa Kasie Kasubun, Kecamatan Padang Ulak Tanding, Kabupaten Rejang Lebong, Bengkulu yang diperkosa dan dibunuh oleh 14 orang pelaku?

Dari berbagai kasus kekerasan seksual terhadap anak di atas, menunjukkan semakin maraknya kasus kekerasan seksual terhadap anak akhirakhir ini sehingga menjadi perhatian publik. Untuk mengoptimalkan perlindungan terhadap anak,

${ }^{3}$ Reza Gunadha, Bocah Korban Sodomi Emon Kembali Bertambah Jadi 73 Orang, Tribun Jabar, (diakses dari http://www.tribunnews.com/ regional/2014/05/05/bocah-korban-sodomi-emon-kembali-bertambahjadi-73-orang, Tanggal 16 September 2017, Pukul: 11:56 WIB)

${ }^{4}$ Robertus Belarminus, Setubuhi Keponakan Berusia 13 Tahun Seorang Paman Masuk Bui,(diaksesdari:http://megapolitan.kompas.com/

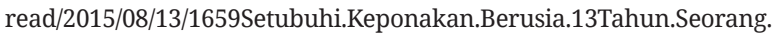
Paman.Masuk.Bui, Pada tanggal 16 September 2017, Pukul: 13:37 WIB)

${ }^{5}$ Hendra Gunawan, Bocah Disodomi Sebelum Cabuli Korban Iwan Ritual Keris, Tribun Jakarta, (diakses dari: http://www.tribunnews. com/metropolitan/2015/09/13/sebelum-cabuli-korban-iwan-lakukanritual-keris, Pada Tanggal 16 September 2017, Pukul: 13:47 WIB)

${ }_{6}^{6}$ Eko Priliawito, Bayu Nugraha, Muhammad Iqbal, Fakta Pembunuhan Dalam Kardus dan Jejak Agus Darmawan, Viva.co.id (diakses dari http://metro.news.viva.co.id/news/read/685292-faktapembunuhan-dalam-kardus-dan-jejak-agus-darmawan, Pada tanggal 16 September 2017, Pukul: 14:00 WIB)

7 Yuliardi Hardjo Putro, Kronologi Kasus Kematian Yuyun ditangan 14 ABG Bengkulu, (diakses dari http://regional.liputan6. com/read/2499720/kronologi-kasus-kematian-yuyun-di-tangan-14abg-bengkulu, pada tanggal 16 September 2017, Pukul: 15:00 WIB) 
pemerintah telah mengeluarkan UU No. 1 Tahun 2016 tentang Perlindungan Anak, yang berisi tentang tindakan kebiri bagi pelaku kejahatan seksual terhadap anak.

Masalah menetapkan jenis sanksi dalam pidana tidak terlepas dari masalah penetapan tujuan yang ingin dicapai dalam pemidanaan. Dengan kata lain, perumusan tujuan pemidanaan diarahkan untuk dapat membedakan sekaligus mengukur sejauh mana jenis sanksi, baik yang berupa "pidana" maupun "tindakan" yang telah ditetapkan pada tahap kebijakan legislasi itu dapat mencapai tujuan secara efektif. Meski jenis sanksi untuk setiap bentuk kejahatan berbeda-beda, namun yang jelas semua penerapan sanksi dalam hukum pidana harus tetap berorientasi pada tujuan pemidanaan itu sendiri ${ }^{8}$. Tindakan kebiri didalam perspektif hukum islam dan hukum positif Indonesia menjadi suatu pro dan kontra dimana terjadi perbedaan pendapat yang timbul dimasyarakat terhadap tindakan kebiri tersebut.

\section{Pengertian Kebiri dan Pemidanaan Pengertian Kebiri}

Kebiri adalah salah satu bentuk hukuman (punishment) atau tindakan/ perawatan (treatment) dengan menyuntikkan obat antiandrogen, seperti medroxyprogesterone acetate atau cyproterone. Yakni Obat-obatan yang dapat menekan fungsi hormon testosteron. untuk menurunkan level testosteron, yakni hormon laki-laki, yang bertanggung jawab pada timbulnya libido9.

\section{Pengertian Pemidanaan}

Pemidanaan bisa diartikan sebagai tahap penetapan sanksi dan juga tahap pemberian sanksi dalam hukum pidana. Kata "pidana" pada umumnya diartikan sebagai hukum, sedangkan "pemidanaan" diartikan sebagai penghukuman. Doktrin membedakan hukum pidana materil dan hukum pidana formil. J.M. Van Bemmelen menjelaskan kedua hal tersebut sebagai berikut:

${ }^{8}$ M. Solehuddin, Sistem Sanksi Dalam Hukum Pidana Ide dasar Double Track system dan Implementasinya, (Jakarta: Raja Grafindo Persada, 2003), hal.7.

${ }^{9}$ Supriyadi Widodo Eddyono, Menguji Euforia Kebiri, hal. 17, (diakses dari jurnal dalam icjr.or.id/data/wp-content/uploads/2016/02/ Menguji-Eforia-Kebiri.pdf, pada Tanggal 22 Oktober 2016, Pukul 11:25 WIB)
"Hukum pidana materil terdiri atas tindak pidana yang disebut berturut-turut, peraturan umum yang dapat diterapkan terhadap perbuatan itu, dan pidana yang diancamkan terhadap perbuatan itu. Hukum pidana formil mengatur cara bagaimana acara pidana seharusnya dilakukan dan menentukan tata tertib yang harus diperhatikan pada kesempatan itu"10.

Tirtamidjaja menjelaskan hukum pidana meteril dan hukum pidana formil sebagai berikut:

1. Hukum pidana materil adalah kumpulan aturan hukum yang menentukan pelanggaran pidana, menetapkan syarat-syarat bagi pelanggar pidana untuk dapat dihukum, menunjukkan orang dapat dihukum dan dapat menetapkan hukuman ataas pelanggaran pidana.

2. Hukum pidana formil adalah kumpulan aturan hukum yang mengatur cara mempertahankan hukum pidana materil terhadap pelanggaran yang dilakukan orang-orang tertentu, atau dengan kata lain mengatur cara bagaimana hukum pidana materil diwujudkan sehingga memperoleh keputusan hakim serta mengatur cara melaksanakan putusan hakim ${ }^{11}$.

\section{Tujuan Pemidanaan}

Di Indonesia sendiri, hukum positif belum pernah merumuskan tujuan pemidanaan. Selama ini wacana tentang tujuan pemidanaan tersebut masih dalam tataran yang bersifat teoritis. Namun sebagai bahan kajian, Rancangan KUHP Nasional telah menetapkan tujuan pemidanaan pada Buku Kesatu Ketentuan Umum dala Bab II dengan judul Pemidanaan, Pidana dan Tindakan. Tujuan pemidanaan menurut Wirjono Prodjodikoro, yaitu ${ }^{12}$ : 1) Untuk menakut-nakuti orang jangan sampai melakukan kejahatan baik secara menakutnakuti orang banyak (generals preventif) maupun menakut-nakuti orang tertentu yang sudah melakukan kejahatan agar dikemudian hari tidak melakukan kejahatan lagi (speciale preventif), atau

2) Untuk mendidik atau memperbaiki orang-orang yang melakukan kejahatan agar menjadi orang-

\footnotetext{
${ }^{10}$ Leden Marpaung, Asas-Teori-Praktik Hukum Pidana, (Jakarta: Sinar Grafika, 2005), hal. 2

${ }^{11}$ Ibid

12 Wirjono Prodjodikoro, Hukum Acara Pidana di Indonesia, (Bandung: Sumur Bandung, 1981), hal. 16
} 
orang yang baik tabiatnya sehingga bermanfaat bagi masyarakat.

Tujuan pemidanaan itu sendiri diharapkan dapat menjadi sarana perlindungan masyarakat, rehabilitasi dan resosialisasi, pemenuhan pandangan hukum adat, serta aspek psikologi untuk menghilangkan rasa bersalah bagi yang bersangkutan. Meskipun pidana merupakan suatu nestapa tetapi tidak dimaksudkan untuk menderitakan dan merendahkan martabat manusia. P.A.F. Lamintang menyatakan ${ }^{13}$ :

Pada dasarnya terdapat tiga pokok pemikiran tentang tujuan yang ingin dicapai dengan suatu pemidanaan, yaitu:

1) Untuk memperbaiki pribadi dari penjahat itu sendiri,

2) Untuk membuat orang menjadi jera dalam melakukan kejahatan- kejahatan, dan

3) Untuk membuat penjahat-penjahat tertentu menjadi tidak mampu untuk melakukan kejahatan-kejahatan yang lain, yakni penjahat yang dengan cara-cara yang lain sudah tidak dapat diperbaiki lagi

Metode pendekatan yang digunakan dalam penyusunan penelitian ini adalah pendekatan yuridis normatif, dengan data sekunder sebagai sumbernya.

\section{Tindakan Kebiri Bagi Pelaku Kekerasan Seksual Terhadap Anak Dalam Perspektif Hukum Islam}

Hukum Islam adalah aturan-aturan yang bersumber dari ajaran-ajaran islam yang biasa disepadangkan dengan istilah "syariat dan fiqih" ${ }^{2}$. Hukuman dalam istilah arab sering disebut 'uqubah yaitu bentuk balasan bentuk balasan bagi seseorang yang atas perbuatannya melanggar ketentuan "syara” yang ditetapkan Allah dan Rasul-Nya untuk kemaslahatan manusia. Tujuan dari hukuman dalam syariat islam merupakan realisasi dari tujuan hukum islam itu sendiri, yakni sebagai pembalasan perbuatan jahat, pencegahan secara umum dan khusus serta perlindungan terhadap hak-hak si

13 P.A.F Lamintang, Hukum Penitensier Indonesia,(Bandung: Armico, 1988), hal.23

14 Departemen Pendidikan Nasional, Kamus Besar Bahasa Indonesia, Edisi IV Cet. I, (Jakarta:Gramedia Pustaka Utama,2008), hal. 363 korban. Sehingga pemidanaan dimaksudkan untuk mendatangkan kemaslahatan umat dan mencegah kezaliman atau kemudaratan ${ }^{15}$.

Istilah "Hukum Islam" merupakan istilah khas Indonesia, sebagai terjemahan al-fiqh al-Islamy atau dalam konteks tertentu dalam al-syariah al-Islamy. Istilah ini dalam wacana ahli hukum barat digunakan Islamic Law. Dalam Al-Qur'an maupun al-Sunnah, istilah al-hukm al-islam tidak dijumpai. Yang digunakan adalah kata syariah yang dalam penjabarannya kemudian lahir istilah fiqh. Penggunaannya dalam Al-Qur'an diartikan sebagai jalan yang jelas yang membawa kemenangan . Dalam terminologi ulama Ushul al-Fiqh, syariah adalah titah (khitab) Allah yang berhubungan dengan perbuatan mukallaf (Muslim, Baligh, dan berakal sehat), baik berupa tuntutan, pilihan, atau perantara (sebab, syarat, atau penghalang) ${ }^{16}$.

Abdul Qadir Audah mengatakan bahwa contoh paling konkret pada masa kini adalah banyaknya pihak yang tidak mau menerima hukum Islam. Mereka menggantinya dengan hukum positif yang merupakan buatan manusia. Padahal, wajib menjadikan hukum Islam untuk mengatur kehidupan sehari-hari ${ }^{17}$. Sebaliknya, haram menjadikan hukum Non Islam untuk mengatur kehidupan sehari-hari. Fuqaha pun sepakat bahwa setiap aturan hukum yang bertentangan dengan prinsip syariat dianggap sebagai hukum yang batil dan tidak wajib menaatinya.

Audah menambahkan barangsiapa secara tegas menolak eksistensi hukum pidana Islam, seperti sanksi potong tangan, sanksi qadzf, dan sanksi zina dengan dalih menyalahi HAM, maka ia kafir. Akan tetapi, kalau tidak menerimanya bukan karena ingkar dan sengaja menolak hukum Allah, maka ia zalim. Sementara itu, apabila tidak menerima hukum Allah karena perlakuan diskriminasi, maka ia fasik ${ }^{18}$.

Bahwasanya norma hukum harus bersifat adil merupakan salah satu pernyataan normatif yang tidak selalu terpenuhi karena dalam praktik tidak jarang ada hukum yang secara objektif dinilai tidak

15 Makhrus Munajat, Dekonstruksi Hukum Pidana Islam, (Yogyakarta: Logung, 2004), hal. 39

${ }^{16}$ Ahmad Rofiq, Hukum Perdata Indonesia, (Depok: RajaGrafindo Persada,2015), hal.1

${ }^{17}$ Abdul Qodir Audah, AL-Tasyri Al-Jina'I Al-Islami, jilid II, hlm 707

${ }^{18}$ Abdul Qodir Audah, AL-Tasyri Al-Jina’I Al-Islami, jilid II, hlm 709 
adil. Adil atau tidak adil pada hakikatnya adalah penilaian moral, dan bukan hanya penilaian hukum. Maka, dalam hal ini menjadi nyata bahwa norma hukum dan norma moral kendati perlu dibedakan bukanlah dua hal yang sama sekali terpisah satu sama lain. Bagaimanakah hubungan antara keduanya dapat diterangkan? Pertama-tama kalau memperhatikan aturan-aturan hidup bersama yang dijadikan norma hukum, menjadi nyata bahwa dalam aturan-aturan tersebut tercermin pula norma-norma moral. Dalam hal ini, norma moral menjadi sama dengan norma hukum. Misalnya: norma moral jangan melakukan kekerasan seksual pada anak dalam banyak masyarakat sudah dijadikan norma hukum. Hukum adalah ungkapan public moralitas social yang dapat dituntut pelaksanaannya dan ditindak pelanggarannya. Dengan demikian hanya terbatas pada dimensi publik kehidupan manusia dalam masyarakat. Hukum tidak dapat mengganti ataupun mewakili moralitas. Tindakan yang benar atau absah secara hukum belum tentu benar atau baik secara moral. Dan sebaliknya, meskipun pada umumnya tindakan yang tidak sah secara hukum juga tidak baik secara moral, kalu kebetulan hukum yang ada adalah hukum yang tidak adil, tindakan yang baik secara moral dapat saja tidak sah secara hukum.

Dalam Hukum Islam, ada kitab yang secara khusus untuk mengatasi tindak pidana dalam hukum pidana islam dinamakan sebagai fiqh jinayah memiliki sistematika pembahasan yang lebih terperinci, aktual dan akomodatif karena selalu menyesuaikan dengan ilmu hukum pidana yang berkembang dan diperbandingkan dengan undang-undang yang berlaku di suatu negara.

Al-Shabuni mengatakan bahwa kelompok khawarij berkeyakinan kalau hukuman rajam tidak termasuk syariat islam. Mereka mempunyai tiga alasan yang menurutnya sangat lemah, lebih lemah daripada sarang laba-laba. ${ }^{19}$

a. Hukuman rajam terlalu sadis. Jika memang disyariatkan oleh islam, pasti disebutkan didalam Al-Qur'an. Namun, semua orang mengetahui bahwa tidak ada satu ayatpun di dalam Al-Qur'an yang menyebutkan tentang rajam.

${ }^{19}$ Muhammad Ali Al-Shabuni, Rawa'I' Al-Bayan fi tafsir Ayat Al-Ahkam min Al-Qur'an, hal.21 b. Zina yang dilakukan oleh hamba sahaya dikelai setengah dari hukuman orang merdeka. Kalau yang dibagi dua ini berkenaan dengan jumlah seratus kali cambuk tidak masalah. Akan tetapi, jika kaitannya dengan hukuman rajam dilempari batu hingga meninggal, maka tidak dapat dibagi dua. Tidak mungkin ada hukuman setengah mati. Dengan demikian jenis hukuman ini tidak sah diberlakukan bagi hamba sahaya.

c. Karena hukuman bagi pelaku zina itu sifatnya umum, maka pengkhususan hukuman bagi pezina muhson menyalahi Al-Qur’an.

Ketiga argumentasi kaum Khawarij diatas dibantah oleh Ahlusunnah. Mereka berpendapat sebagai berikut:

a. Tidak disebutkannya hukuman rajam didalam Al-Qur'an bukan berarti tidak disyariatkan. Banyak ketentuan yang tidak disebutkan didalam Al-Qur'an, tetapi diuraikan secara jelas di dalam hadis. Jangan lupa, Allah menyuruh kita untuk selalu mengikuti Rasullulah dan melaksanakan semua perintahnya. Allah berfirman:

Apa yang diberikan Rasul kepadamu, maka terimalah. Dan apa yang dilarangnya bagimu, maka tinggalkanlah. (QS. Al-Hasyr (59):7). Selain, kita juga yakin bahwa segala aktivitas Rasulullah berdasarkan wahyu, seperti firman Allah berikut:

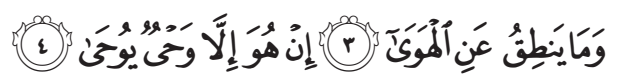

"Dan tiadalah yang diucapkannya itu (Al-Quran) menurut kemauan hawa nafsunya.ucapannya itu tiada lain hanyalah wahyu yang diwahyukan (kepadanya)”. (QS. Al-Najm (53):3-4).

Dengan demikian, bagaimana mereka beranggapan bahwa hukuman rajam tidak disyariatkan oleh islam, Padahal Rasulullah pernah melaksanakan bersama para sahabat. Adapun tentang peranan dan fungsi Rasulullah disebutkan secara jelas dalam Al-Qur’an.

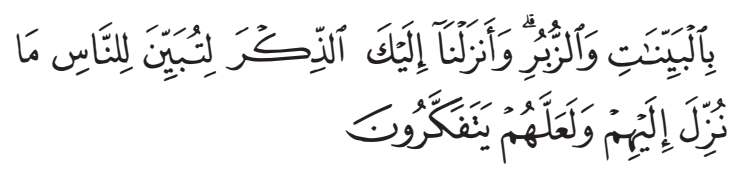

"Keterangan-keterangan (mukjizat) dan kitabkitab. dan Kami turunkan kepadamu Al Quran, agar kamu menerangkan pada umat manusia apa yang telah diturunkan kepada mereka[829] 
dan supaya mereka memikirkan.” (QS. Al-Nahl (16): 44)

b. Berbeda dengan rajam yang tidak secara tegas disebutkan didalam Al-Qur'an, sanksi cambuk bagi pelaku jarimah zina ghairu muhsoan secara eksplisit ditegaskan di dalam firman Allah:

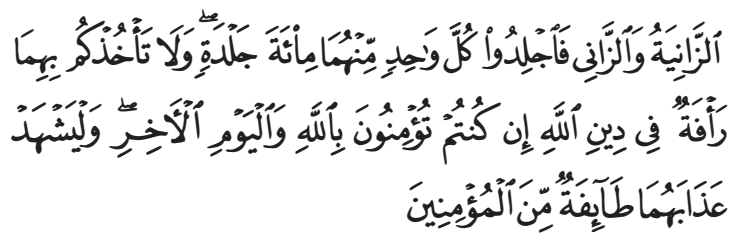

"Perempuan yang berzina dan laki-laki yang berzina, Maka deralah tiap-tiap seorang dari keduanya seratus dali dera, dan janganlah belas kasihan kepada keduanya mencegah kamu untuk (menjalankan) agama Allah, jika kamu beriman kepada Allah, dan hari akhirat, dan hendaklah (pelaksanaan) hukuman mereka disaksikan oleh sekumpulan orang-orang yang beriman. (QS. AlNur (24): 2)

Ayat di atas tidak menyebutkan jumlah cambukan, tetapi juga larangan untuk berbelas kasih kepada pelaku. Selain itu, proses eksekusi hendaknya disaksikan oleh kaum muslimin agar menimbulkan efek jera dan dapat dijadikan pelajaran berharga. Adapun hadis yang menjelaskan sanksi pengasingan sebagai pelengkap dari sanksi cambuk adalah:

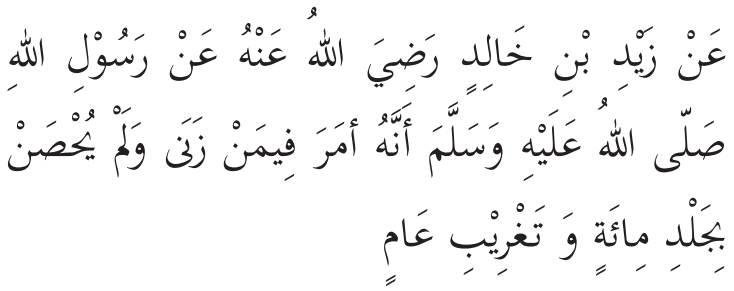

Dari Zaid bin Khalid Al-Juhani, ia menanyakan," Aku mendengar Rasulullah memerintahkan agar orang yang berzina ghairu muhson dicambuk seratus kali dan diasingkan selama satu tahun." (HR. Al-Bukhari)”20

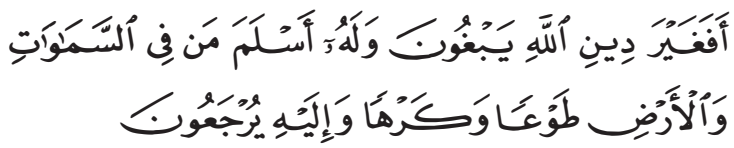

"Maka apakah mereka mencari agama yang lain dari agama Allah, Padahal kepada-Nya-lah menyerahkan diri segala apa yang di langit dan di bumi, baik dengan suka maupun terpaksa dan

${ }^{20}$ Al-Bukhari, Sahih Al-Bukhari, jilid IV, hlm.2733 hanya kepada Allahlah mereka dikembalikan. (QS. Ali Imron: 83)

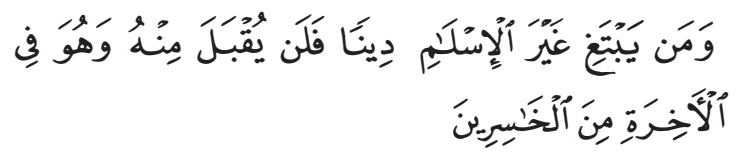

Siapa mencari agama selain agama Islam, maka sekali-kali tidaklah akan diterima (agama itu) daripadanya, dan Dia di akhirat Termasuk orangorang yang rugi. (Ali Imron: 85)

Ditinjau dari unsur-unsur jarimah atau tindak pidana, objek utama kajian fiqh jinayah dapat dibedakan menjadi 3 bagian yaitu ${ }^{21}$ :

1) Al-rukn al-syar'i atau unsur formil (unsur yang menyatakan bahwa seseorang dapat dinyatakan sebagai pelaku jarimah jika ada undang-undang yang secara tegas melarang dan menjatuhkan sanksi kepada pelaku tindak pidana

2) Al-rukn al-madi atau unsur materiil adalah unsur yang menyatakan bahwa seseorang dapat dijatuhkan pidana jika ia benar-benar terbukti melakukan sebuah jarimah, baik yang bersifat positif(aktif dalam melakukan sesuatu) maupun yang bersifat negatif (pasif dalam melakukan sesuatu).

3) Al-rukn al-adabi atau unsur moril adalah unsur yang menyatakan bahwa seseorang dapat dipersalahkan jika ia bukan orang gila, anak dibawah umur atau sedang dibawah ancaman. Itulah objek utama kajian fiqh jinayah jika dikaitkan dengan unsur-unsur tindak pidana atau arkan al-jarimah. sementara itu, jika dikaitkan dengan materi pembahasan, dimana hal ini erat hubunganya dengan unsur materiil atau rukn al-madi maka objek kajian fiqh jinayah meliputi 3 masalah pokok jarimah qishash, jarimah hudud, jarimah ta'zir.

Kebiri adalah salah satu bentuk hukuman (punishment) atau tindakan/ perawatan (treatment) dengan menyuntikkan obat antiandrogen, seperti medroxy progesterone acetate atau cyproterone. Yakni Obat-obatan yang dapat menekan fungsi hormon testosteron. untuk menurunkan level testosteron, yakni hormon laki-laki, yang bertanggung jawab pada timbulnya libido ${ }^{22}$.

${ }^{21}$ Nurul Irfan dan Masyrofah, fiqh jinayat, (Jakarta: AMZAH, 2016), hal. 2

${ }^{22}$ Supriyadi Widodo Eddyono, Menguji Euforia Kebiri, hal. 17, 
Dengan demikian dari defenisi operasional variabel dan ruang lingkup penelitian diatas maka yang dimaksud dengan hukuman kebiri bagi pelaku kejahatan seksual anak ditinjau dari hukum Islam adalah (al ikhsha, castration) artinya adalah pemotongan dua buah dzakar (al khushyatain, testis), yang dapat dibarengi dengan pemotongan penis (dzakar). Jadi kebiri dapat berupa pemotongan testis saja, dan inilah pengertian dasar dari kebiri. Namun adakalanya kebiri berupa pemotongan testis dan penis sekaligus. Kebiri bertujuan menghilangkan syahwat dan sekaligus menjadikan mandul. Metode kebiri secara garis besar ada dua macam, yaitu metode fisik dan metode hormonal (injeksi). Metode fisik dilakukan dengan cara memotong organ yang memproduksi testosteron, yaitu testis. Setelah testis dipotong dan dibuang melalui operasi, sisanya diikat dan kemudian dijahit. Dengan pemotongan testis tersebut, berarti sudah dihilangkan testosteron sebagai hormon pembangkit gairah seks. Akibatnya laki-laki akan kehilangan gairah seks dan sekaligus menjadi mandul permanen.

Adapun metode kebiri hormonal, dilakukan bukan dengan memotong testis atau penis, tapi dengan cara injeksi (suntikan) hormon kepada orang yang dikebiri. Ada dua metode injeksi. Pertama, diinjeksikan obat yang menekan produksi hormon testosteron. Injeksi dilakukan berulang-ulang sehingga hormon testosterone seolah-olah hilang. Kedua, diinjeksikan hormon estrogen kepada orang yang dikebiri, sehingga ia memiliki ciri-ciri fisik seperti perempuan. Hormon testosteron akan menurun dan gairah seksual juga akan ikut menurun.

Perlu diketahui menurut mayoritas ulama islam, menjatuhkan hukuman kebiri bagi pelaku kekerasan seksual hukumnya adalah haram. Tentu saja para ulama tidak serta merta mengeluarkan fatwa tanpa tahap penelitian dan pembahasan panjang, justru para ulama telah membahas dan meneliti permasalahan ini. Kebiri bertujuan menghilangkan syahwat dan sekaligus menjadikan mandul. Islam tidak membenarkan pengebirian terhadap manusia berdasarkan beberapa hadis berikut:

(diakses dari jurnal dalam icjr.or.id/data/wp-content/uploads/2016/02/ Menguji-Eforia-Kebiri.pdf, pada Tanggal 2 September 2017, Pukul 11:25 WIB)
Pertama, Dalam kitab Al-Ahkam Al-Fiqhiyyah Al-Muta’alliqah bi Al Syahwat, Syekh 'Adil Mathrudi berkata:

"Para Ulama telah sepakat bahwa kebiri pada manusia itu diharamkan dan tidak boleh.” ('Adil Mathrudi, Al-Ahkam Al Fiqhiyyah Al Muta'alliqah bi Al Syahwat, hlm.88).

Kedua, syariah Islam telah menetapkan hukuman untuk pelaku pedofilia yang melakukan tindakan pencabulan dan pemerkosaan sesuai rincian fakta perbuatannya, sehingga tidak boleh (haram) melaksanakan jenis hukuman di luar ketentuan Syariah Islam itu. Dalil haramnya melaksanakan hukum-hukum non syariah adalah firman Allah SWT:

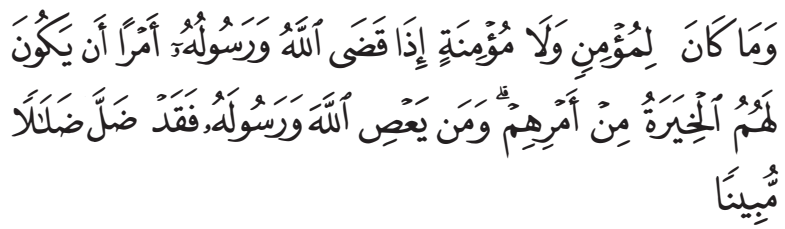

"Dan tidaklah patut bagi laki-laki yang mukmin dan tidak (pula) bagi perempuan yang mukmin, apabila Allah dan Rasul-Nya telah menetapkan suatu ketetapan, akan ada bagi mereka pilihan (yang lain) tentang urusan mereka. dan Barangsiapa mendurhakai Allah dan Rasul-Nya Maka sungguhlah Dia telah sesat, sesat yang nyata." (QS. Al-Ahzab: 36)

Ayat tersebut dengan jelas melarang muslim untuk membuat suatu ketentuan baru apabila sudah ada ketentuan hukum yang tertentu dari Syariah Islam. Maka dari itu haram hukumnya menerapkan hukum kebiri untuk pelaku kekerasan seksual, karena Syariah Islam sudah menetapkan rincian hukuman tertentu bagi pelaku kekerasan seksual.

Ketiga, metode kebiri yang digunakan adalah metode injeksi kedua, yakni yang diinjeksikan adalah hormon estrogen, hukumnya juga haram dari sisi lain, karena mengakibatkan laki-laki yang dikebiri memiliki ciri-ciri fisik seperti perempuan. Padahal Islam telah mengharamkan laki-laki menyerupai perempuan atau sebaliknya perempuan menyerupai laki-laki. Dalil keharamannya adalah hadis riwayat Ibnu Abbas RA bahwa:

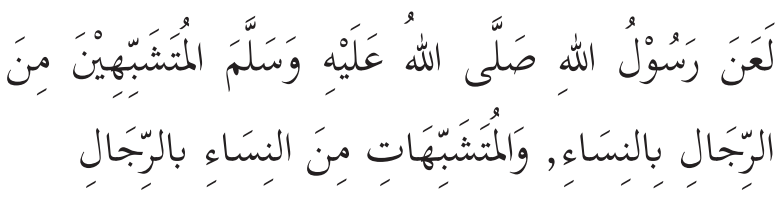


"Rasulullah Shallallahu 'alaihi wa sallam melaknat laki-laki yang menyerupai wanita dan wanita yang menyerupai laki-laki.” (HR. Al-Bukhari no. 5885, 6834)

Hadis ini mengharamkan perbuatan laki-laki menyerupai wanita atau perbuatan wanita menyerupai laki-laki. Maka, metode kebiri dengan cara injeksi hormon estrogen kepada laki-laki pelaku seksual haram hukummya, karena menjadi perantaraan (wasilah) bagi laki-laki itu untuk menyerupai lawan jenisnya (perempuan). Kaidah fiqih dalam masalah ini menyebutkan:

$$
\text { الوسيلة إلى الحرام محرمة }
$$

"Al-Wasilah ila al-haram muharromah."

"Segala perantaraan menuju yang haram hukumnya haram juga.

Berdasarkan 3 (tiga) alasan di atas, menjatuhkan hukuman kebiri bagi pelaku seksual hukumnya adalah haram.

Syariah Islam sudah menetapkan rincian hukuman tertentu bagi pelaku seksual yang melakukan tindakan pencabulan dan pemerkosaan. Adapun rincian hukuman untuk pelaku seksual sebagai berikut:

1. Jika yang dilakukan pelaku seksual adalah perbuatan zina, hukumannya adalah hukuman untuk pezina (had az zina), yaitu dirajam jika sudah muhshan (menikah) atau dicambuk seratus kali jika bukan muhshan.

2. Jika yang dilakukan pelaku seksual adalah liwath (homoseksual), maka hukumannya adalah hukuman mati, bukan yang lain.

3. Jika yang dilakukan adalah pelecehan seksual (at taharusy al jinsi) yang tidak sampai pada perbuatan zina atau homoseksual, hukumannya ta’zir.

\section{Tindakan Kebiri Bagi Pelaku Kekerasan Seksual Terhadap Anak Dalam Perspektif Hukum Positif Indonesia}

Menurut Sunaryati Hartono dalam bukunya yang berjudul "Politik Hukum Menuju Satu Sistem Hukum Nasional” menyatakan bahwa hukum sebagai alat bahwa secara praktis politik hukum merupakan alat atau sarana dan langkah yang dapat digunakan oleh pemerintah untuk menciptakan sistem hukum nasional yang dapat dipergunakan untuk mencapai cita-cita bangsa dan tujuan negara ${ }^{23}$.

Politik hukum nasional adalah arah yang harus ditempuh dalam pembuatan dan penegakan hukum serta upaya menjadikan hukum sebagai proses guna mencapai cita-cita dan tujuan bangsa dan negara, cita hukum dan kaidah penuntun hukum di Indonesia sebagaimana terkandung dalam Pembukaan UndangUndang Dasar Negara Republik Indonesia Tahun 1945 yang menempatkan Pancasila sebagai paradigma politik hukum dan merupakan platform kehidupan bersama bagi bangsa Indonesia yang sangat majemuk dan tetap terikat erat sebagai bangsa yang bersatu ${ }^{24}$.

Sudarto berpandangan bahwa politik hukum adalah, Pertama: usaha untuk mewujudkan peraturan-peraturan yang lebih baik sesuai dengan keadaan dan situasi pada suatu saat. Kedua: kebijakan dari suatu negara melalui badan-badan yang berwenang untuk menetapkan peraturanperaturan yang dikehendaki yang diperkirakan dapat digunakan untuk mengekspresikan apa yang terkandung dalam masyarakat dan untuk mencapai apa yang dicita-citakan ${ }^{25}$.

Kebijakan yang telah direkomendasikan untuk dipilih oleh policy makers bukanlah jaminan bahwa kebijakan tersebut pasti berhasil dalam implementasinya. Ada banyak variabel yang mempengaruhi keberhasilan implementasi kebijakan baik yang bersifat individual maupun kelompok atau institusi ${ }^{26}$. Sebagai negara yang pancasilias serta menjunjung tinggi nilai-nilai kebangsaan dan kemanusiaan, Indonesia memiliki banyak peraturan yang secara tegas memberikan upaya perlindungan anak ${ }^{27}$, namun peraturan tersebut telah memberikan upaya perlindungan atau tidak, itulah yang masih menjadi permasalahan.

Berikut regulasi kebijakan hukum bagi pelaku kekerasan seksual terhadap anak dapat diidentifikasikan diantaranya:

${ }^{23}$ Satjipto Rahardjo, Ilmu Hukum, Cet III, (Bandung: Citra Aditya Bakti, 1991), hal. 352-353

${ }^{24}$ Mahfud MD, Membangun Politik Hukum Menegakkan Konstitusi, (Jakarta: LP3ES, 2006), hal. 30-31

${ }_{25}$ Sudarto, Hukum dan Hukum Pidana, (Bandung: Alumni, 1981), hal. 159

${ }^{26}$ AG. Subarsono, Analisa Kebijakan Publik Konsep, Teori dan Aplikasi, (Yogyakarta: Pustaka Pelajar, 2015), hal. 87

${ }^{27}$ Nasir Djamil, Anak Bukan Untuk Dihukum, (Jakarta: Sinar Grafika, 2015), hal. 27 
a. Pasal 289 sampai dengan pasal 296 KUHP

b. Pasal 81 dan Pasal 82 Undang-Undang No. 23 Tahun 2002 tentang Perlindungan Anak,

c. UU No. 35 Tahun 2014 tentang Perubahan Atas UU No. 23 Tahun 2002 tentang Perlindungan Anak

d. UU No. 1 Tahun 2016 tentang perubahan dua pasal dari UU Nomor 23 Tahun 2002 tentang Perlindungan Anak, yakni pasal 81, disisipkan satu Pasal 81A. Kemudian Pasal 82, disisipkan satu Pasal 82A.

Yang mengatur tentang tindakan kebiri, terdapat pada Pasal 1 ayat (7), yang berbunyi:

\section{Pasal 81}

(4) Selain terhadap pelaku sebagaimana dimaksud pada ayat (3), penambahan 1/3 (sepertiga) dari ancaman pidana juga dikenakan kepada pelaku yang pernah dipidana karena melakukan tindak pidana sebagaimana dimaksud dalam Pasal 76D;

(5) Dalam hal tindak pidana sebagaimana dimaksud dalam Pasal 76D menimbulkan korban lebih dari 1 (satu) orang, mengakibatkan luka berat, gangguan jiwa, penyakit menular, terganggu atau hilangnya fungsi reproduksi, dan/atau korban meninggal dunia, pelaku dipidana mati, seumur hidup, atau pidana penjara paling singkat 10 (sepuluh) tahun dan paling lama 20 (dua puluh) tahun;

(7) Terhadap pelaku sebagaimana dimaksud ayat (4) dan ayat (5) dapat dikenai tindakan berupa kebiri kimia dan pemasangan pendeteksi elektronik;

Berbagai upaya pemerintah dalam menanggulangi kekerasan seksual terhadap anak termasuk dalam melakukan pembaharuan hukum guna memberikan perlindungan terhadap anak sebagai korban kekerasan seksual yaitu dengan dikeluarkannya UU No. 23 Tahun 2002, UU No. 35 Tahun 2014 sampai dengan dikeluarkan UU No. 1 Tahun 2016 tentang Perlindungan Anak. UU No. 1 Tahun 2016 yang berisi adanya tindakan kebiri bagi pelaku kekerasan seksual terhadap anakdikeluarkan karena berulangnya kasus kekerasan seksual terhadap anak yang sangat memprihatinkan, sehingga maraknya kasus kekerasan seksual terhadap anak akhir-akhir ini menjadi perhatian publik.
Eksistensi tindakan kebiri dilihat dari sudut pandang Pancasila apakah bertentangan dengan Amandemen Kedua UUD 1945 dan UU No. 39 Tahun 1999 tentang Hak Asasi Manusia yang menyatakan bahwa: "setiap orang berhak untuk hidup" (Pasal 28A Jo Pasal 28 ayat (1) UUD 1945 dan Pasal 9 ayat 1 jo Pasal 4 UU HAM); dan "Setiap orang berhak untuk bebas dari penghilangan paksa dan penghilangan nyawa” (Pasal 33 ayat 2 UU HAM). Terhadap masalah di atas, dapat dikemukakan hal-hal sebagai berikut:

a. Dilihat sebagai satu kesatuan, Pancasila mengandung nilai keseimbangan antara sila yang satu dengan sila lainnya. Namun, apabila Pancasila dilihat secara parsial (menitikberatkan pada salah satu sila), maka ada pendapat yang menyatakan bahwa tindakan kebiri bertentangan dengan Pancasila dan ada pula yang menyatakan tidak bertentangan dengan Pancasila. Jadi, pendapat yang menolak dan menerima kebiri sama-sama mendasarkan pancasila.

Hal ini terlihat dalam penelitian yang pernah dilakukan oleh Fakultas Hukum UNDIP bekerjasama dengan Kejaksaan Agung pada tahun 1981 dinyatakan bahwa "ada kecenderungan diantara mereka yang pro dan kontra untuk menjadikan Pancasila sebagai "justification"28.

b. Jenis pidana tidak dapat begitu saja dihadapkan secara diametral dengan HAM begitupun tindakan kebiri karena pada hakikatnya semua jenis pidana bertentangan dengan HAM. Hal ini sama dengan "hak kebebasan pribadi" (Pasal 4 UU HAM) atau "hak atas kemerdekaan" (Pembukaan UUD 1945) yang juga tidak dapat dihadapkan secara diametral dengan "pidana penjara”. Apabila dihadapkan secara diametral, berarti pidana "penjara” pun bertentangan dengan UUD 1945 dan UU HAM karena pidana penjara pada hakikatnya adalah "perampasan kemerdekaan”. Sama halnya dengan pidana mati bahwa dalam Pasal 6 ayat (2) ICCPR dinyatakan bahwa pidana mati tetap dimungkinkan untuk "the most serious crimes"29. Maka tindakan

28 Barda Nawawi Arief, Pidana Mati Perspektif Global, Pembaharuan Hukum Pidana dan Alternatif Pidana Untuk Koruptor, (Semarang: Pustaka Magister, 2015), hal. 33

${ }^{29}$ Ibid, hal 36 
kebiri dapat diberikan kepada pelaku kekerasan seksual terhadap anak karena kasus kekerasan seksual terhadap anak saat ini merupakan kejahatan yang serius dan diberikan kepada pelaku kekerasan seksual terhadap anak tidak sembarangan diberikan kepada pelaku, tindakan kebiri diberikan tidak diberikan kepada seluruh pelaku kekerasan seksual terhadap anak tetapi hanya kepada pelaku yang memenuhi unsur dalam UU No. 1 Tahun 2016 tentang Perlindungan Anak.

Terjadi pro-kontra mengenai tindakan kebiri. Dipilihnya tindakan kebiri sebagai salah satu sarana kebijakan kriminal (kebijakan penanggulangan kejahatan), khususnya dalam menanggulangi kekerasan seksual terhadap anak melalui tindakan kebiri merupakan hal yang wajar. Alasan yang dapat dikemukan antara lain:

a. Dilihat dari sudut kebijakan hukum pidana (penal policy):

Kejahatan termasuk bidang kebijakan kriminal (criminal policy). Kebijakan kriminal ini pun tidak terlepas dari kebijakan yang lebih luas yaitu kebijakan sosial (social policy) yang terdiri dari kebijakan /upaya-upaya untuk kesejahteraan sosial (sosial welfare policy) dan kebijakan/upaya-upaya untuk perlindungan masyarakat (social defence policy) ${ }^{30}$. Digunakan dan dipilihnya suatu jenis sanksi pidana (termasuk tindakan kebiri) dalam kebijakan hukum pidana (penal policy), pada dasarnya merupakan bagian dari kebijakan kriminal (criminal policy) dan kebijakan sosial (social policy) yaitu kebijakan untuk mencapai kesejahteraan dan upaya atau kebijakan untuk melakukan pencegahan dan penanggulangan perlindungan masyarakat.

Arah kebijakan hukum bertujuan menjadikan hukum sebagai aturan yang memberikan perlindungan bagi hak-hak warga negara dan menjamin kehidupan generasi dimasa depan ${ }^{31}$. Oleh karena itu, sistem hukum tiap negara dalam praktiknya terus mengalami modernisasi.

${ }^{30}$ Barda Nawawi Arief, Masalah Penegakan Hukum dan Kebijakan Hukum Pidana Dalam Penanggulangan Kejahatan, (Jakarta: Kencana Prenadamedia Group, 2014), hal. 77

${ }^{31}$ Marlina, Peradilan Pidana Anak di Indonesia, (Bandung: Refika Aditama, 2009), hal. 1 b. Dilihat dari sudut upaya pembaharuan hukum di Indonesia.

Usaha pembaharuan hukum di Indonesia yang sudah dimulai sejak lahirnya UUD 1945 tidak dapat dilepaskan dari landasan dan sekaligus tujuan nasional yang ingin dicapai seperti telah dirumuskan dalam Pembukaan UUD $1945^{32}$. Tujuan nasional itu tertuang dalam Alenia Keempat Pembukaan UUD 1945.

Dari perumusan Pembukaan UUD 1945, terlihat dua tujuan nasional yang utama yaitu:

1. Untuk melindungi segenap bangsa Indonesia

2. Untuk memajukan kesejahteraan umum berdasarkan Pancasila

Jadi, terlihat dua kata kunci dari tujuan nasional yaitu "Perlindungan Masyarakat"/ social defence dan "Kesejahteraan Masyarakat"/ social welfare. Tujuan nasional menjadi landasan dan tujuan dari setiap usaha pembaharuan hukum, termasuk pembaharuan hukum pidana, dalam hal ini tujuan penanggulangan kejahatan kekerasan seksual terhadap anak.

Memberikan tindakan kebiri kepada pelaku kekerasan seksual terhadap anak bukan hanya memberikan perlindungan terhadap anak yang menjadi korban kekerasan seksual tetapi memberikan perlindungan terhadap masyarakat luas agar dapat hidup tenang, tentram tanpa adanya rasa takut terhadap anak-anak. Alasan HAM dan martabat manusia yang selalu menjadi pertimbangan terhadap pidana kebiri. Namun, perlu diketahui bahwa HAM bukanlah hanya Hak asasi manusia sebagai mahluk individu, namun HAM adalah hak asasi masyarakat yang harus mendapatkan perlindungan dari pelaku kekerasan seksual.

Kekerasan seksual dipandang sebagai kejahatan yang hanya menjadi urusan privat (individu korban), namun harus dijadikan sebagai problem publik, karena kejahatan ini jelas-jelas merupakan bentuk perilaku yang menonjolkan nafsu, dendam dan superioritas yakni siapa yang kuat itulah yang berhak mengorbankan orang lain ${ }^{33}$. Sejalan dengan

32 Barda Nawawi Arief, Tujuan dan Pedoman Pemidanaan (Perspektif Pembaharuan dan Perbandingan Hukum Pidana), (Semarang: Pustaka Magister,2015), hal. 34

${ }^{33}$ Abdul Wahid dan Muhammad Irfan, Perlindungan Terhadap 
itu, Nusryahbani Kantjasungkana mengemukakan bahwa masalah perkosaan atau kekerasan seksual tidak dapat lagi dipandang sebagai masalah antar individu belaka, tetapi merupakan problem sosial yang terkait dengan masalah hak asasi manusia, khususnya yang berkaitan dengan perlindungan terhadap segala bentuk penyiksaan, kekerasan, kekejaman dan pengabaian martabat manusia ${ }^{34}$. Kekerasan seksual dan penanganannya selama ini menjadi salah satu indikasi dan bukti lemahnya perlindungan (pengayoman) hak asasi dari tindakan kekerasan seksual.

Kekerasan sering terjadi terhadap anak, yang dapat merusak, berbahaya dan menakutkan anak. Anak yang menjadi korban kekerasan menderita kerugian, tidak saja bersifat material tetapi juga bersifat immaterial seperti goncangan emosional dan psikologis yang dapat mempengaruhi kehidupan masa depan anak ${ }^{35}$. Terjadinya kasus kekerasan seksual terhadap anak bahkan disertai dengan pembunuhan memang menuntut keseriusan untuk melindungi anak. Tindakan kebiri diberikan kepada pelaku kekerasan seksual terhadap anak tidak sembarangan diberikan kepada pelaku, tindakan kebiri diberikan tidak diberikan kepada seluruh pelaku kekerasan seksual terhadap anak tetapi hanya kepada pelaku yang memenuhi unsur dalam UU No. 1 Tahun 2016 tentang Perlindungan Anak. Itupun diberikan dengan kehati-hatian dan melalui proses pendeteksi dari kedokteran yaitu kebiri hanya diberikan kepada pelaku yang mempunyai kemampuan ereksi diatas normal, yang berguna untuk menekan dorongan seksual dan menghilangkan kemampuan ereksi.Sehingga diperlukan kebijakan hukum dalam menanggulangi kekerasan seksual terhadap anak.

\section{Penutup}

Berdasarkan uraian di atas, dapat disimpulkan bahwa:

1. Tindakan kebiri bagi pelaku kekerasan seksual terhadap anak dalam perspektif hukum islam

\footnotetext{
Korban Kekerasan Seksual Advokasi Atas Hak Asasi Perempuan, (Bandung: Refika Aditama, 2011), hal. 62

${ }^{34}$ Eko Prasetyo dan Suparman Marzuki, Perempuan Dalam Wacana Pemerkosaan, (Yogyakarta: PKBI- DIY, 1997), hal. 178

${ }^{35}$ Maidin Gultom, Perlindungan Hukum Terhadap Anak dan Perempuan, (Bandung: Refika Aditama, 2014), hal. 1-2
}

bahwa tindakan kebiri melanggar syariat islam sehingga diharamkan dengan tiga alasan yaitu:

a. Syariah Islam dengan tegas telah mengharamkan kebiri pada manusia, tanpa ada perbedaan pendapat (khilafiyah) di kalangan fuqaha,

b. Syariah Islam telah menetapkan hukuman untuk pelaku pedofilia yang melakukan tindakan pencabulan dan pemerkosaan sesuai rincian fakta perbuatannya, sehingga tidak boleh (haram) melaksanakan jenis hukuman di luar ketentuan Syariah Islam itu.

c. Dalam hal metode kebiri yang digunakan adalah metode injeksi kimia, yakni yang diinjeksikan adalah hormon estrogen, hukumnya juga haram dari sisi lain, karena mengakibatkan laki-laki yang dikebiri memiliki ciri-ciri fisik seperti perempuan. Padahal Islam telah mengharamkan laki-laki menyerupai perempuan atau sebaliknya perempuan menyerupai laki-laki.

2. Tindakan kebiri bagi pelaku kekerasan seksual terhadap anak dalam perspektif hukum hukum positif Indonesia bahwa regulasi kebijakan hukum bagi pelaku kekerasan seksual terhadap anak terdapat dalam KUHP dan dikeluarkannya UU No. 23 Tahun 2002, UU No. 35 Tahun 2014 sampai dengan dikeluarkan UU No. 1 Tahun 2016 tentang Perlindungan Anak. UU No. 1 Tahun 2016 yang berisi adanya tindakan kebiri bagi pelaku kekerasan seksual terhadap anak dikeluarkan karena berulangnya kasus kekerasan seksual terhadap anak yang sangat memprihatinkan. Namun penerapan tindakan kebiri bagi pelaku kekerasan seksual terhadap anak di Indonesia, mendapat pro dan kontra mengenai tindakan kebiri. Namun, dipilihnya tindakan kebiri sebagai salah satu sarana kebijakan kriminal (kebijakan penanggulangan kejahatan), khususnya dalam menanggulangi kekerasan seksual terhadap anak.

\section{Pustaka Acuan}

Arief, Barda Nawawi, Masalah Penegakan Hukum dan Kebijakan Hukum Pidana Dalam Penanggulangan Kejahatan,(Jakarta:Kencana Prenadamedia Group, 2014)

Arief, Barda Nawawi, Pidana Mati Perspektif Global, Pembaharuan Hukum Pidana dan Alternatif 
Pidana Untuk Koruptor, (Semarang: Pustaka Magister, 2015)

Arief, Barda Nawawi, Tujuan dan Pedoman Pemidanaan (Perspektif Pembaharuan dan Perbandingan Hukum Pidana), (Semarang: Pustaka Magister, 2015)

Departemen Pendidikan Nasional, Kamus Besar Bahasa Indonesia, Edisi IV Cet. I, (Jakarta: Gramedia Pustaka Utama, 2008)

Djamil, Nasir, Anak Bukan Untuk Dihukum, Catatan Pembahasan UU Sistem Peradilan Pidana Anak (UU-SPPA), (Jakarta Timur: Sinar Grafika, 2015)

Gultom, Maidin, Perlindungan Hukum Terhadap Anak dan Perempuan, (Bandung: Refika Aditama, 2014)

Irfan, Nurul dan Masyrofah, Fiqh Jinayat, (Jakarta, AMZAH, 2016)

Lamintang, P.A.F., Hukum Penitensier Indonesia,(Bandung: Armico, 1988)

Mahfud MD, Moh., Membangun Politik Hukum Menegakkan Konstitusi, (Jakarta: LP3ES, 2006)

Marlina, Peradilan Pidana Anak di Indonesia, (Bandung: Refika Aditama009)

Marpaung, Leden, Asas-Teori-Praktik Hukum Pidana, (Jakarta: Sinar Grafika, 2005)

Munajat, Makhrus, Dekonstruksi Hukum Pidana Islam,(Yogyakarta: Logung, 2004)

Prasetyo, Eko dan Suparman Marzuki, Perempuan Dalam Wacana Pemerkosaan, (Yogyakarta: PKBI- DIY, 1997)

Prodjodikoro, Wirjono, Hukum Acara Pidana di Indonesia,(Bandung: Sumur Bandung, 1981)

Rahardjo, Satjipto, Ilmu Hukum, Cet III, (Bandung: Citra Aditya Bakti, 1991)

Rofiq, Ahmad, Hukum Perdata Indonesia, (Depok: RajaGrafindo Persada, 2015)

Saraswati, Rika, Hukum Perlindungan Anak Di Indonesia,(Bandung: Citra Aditya Bakti, 2015)

Solehuddin, M., Sistem Sanksi Dalam Hukum Pidana Ide dasar Double Track system dan Implementasinya, (Jakarta: Raja Grafindo Persada, 2003).

Subarsono, AG., Analisa Kebijakan Publik Konsep, Teori dan Aplikasi, (Yogyakarta: Pustaka Pelajar, 2015)

Sudarto, Hukum dan Hukum Pidana, (Bandung: Alumni,1981)

Wahid, Abdul dan Muhammad Irfan, Perlindungan Terhadap Korban Kekerasan Seksual Advokasi
Atas Hak Asasi Perempuan, (Bandung: Refika Aditama, 2011)

\section{Website}

Eko Priliawito, Bayu Nugraha, Muhammad Iqbal, Fakta Pembunuhan Dalam Kardus dan Jejak Agus Darmawan, Viva.co.id (diakses dari http:// metro.news.viva.co.id/news/read/685292-faktapembunuhan-dalam-kardus-dan-jejak-agusdarmawan, Pada tanggal 16 September 2017, Pukul: 14:00 WIB)

Hendra Gunawan, Bocah Disodomi Sebelum Cabuli Korban Iwan Ritual Keris, Tribun Jakarta, (diakses dari: http://www.tribunnews.com/ metropolitan/2015/09/13/sebelum-cabuli-korbaniwan-lakukan-ritual-keris, Pada Tanggal 16 September 2017, Pukul: 13:47 WIB)

Reza Gunadha, Bocah Korban Sodomi Emon Kembali Bertambah Jadi 73 Orang, Tribun Jabar, (diakses dari http://www.tribunnews.com/ regional/2014/05/05/bocah-korban-sodomi-emonkembali-bertambah-jadi-73-orang, Tanggal 16 September 2017, Pukul: 11:56 WIB)

Robertus Belarminus, Setubuhi Keponakan Berusia 13 Tahun Seorang Paman Masuk Bui,(diaksesdari:http://megapolitan.kompas. com/read/2015/08/13/1659Setubuhi.Keponakan. Berusia.13Tahun.Seorang.Paman.Masuk.Bui, Pada tanggal 16 September 2017, Pukul: 13:37 WIB)

Supriyadi Widodo Eddyono, Menguji Euforia Kebiri, hal. 17, (diakses dari jurnal dalam icjr.or.id/datal wp-content/uploads/2016/02/Menguji-Eforia-Kebiri. pdf, pada Tanggal 2 September 2017, Pukul 11:25 WIB)

Yuliardi Hardjo Putro, Kronologi Kasus Kematian Yuyun ditangan 14 ABG Bengkulu, (diakses dari http://regional.liputan6.com/read/2499720/ kronologi-kasus-kematian-yuyun-di-tangan-14abg-bengkulu, pada tanggal 16 September 2017, Pukul: 15:00 WIB)

Zachary Edmods Oswald, “Off With His....” Analyzing the Sex Disparity in Chemical Castration Sentences", Michigan Journal of Gender and Law, Vol 19:471,2012-2013, hlm. 484, diakses dari jurnal dalam icjr.or.id/data/wp-content/ uploads/2016/02/Menguji-Eforia-Kebiri.pdf, pada Tanggal 2 September 2017, Pukul 11:25 WIB) 